\title{
Plurilingualism and Interculturalism - Hidden Resources of International Trade
}

\author{
Rosina A. Kakova
}

Department of Foreign Languages, University of Food Technologies, Plovdiv, Bulgaria

\begin{tabular}{|c|c|}
\hline ARTICLE INFO & ABSTRACT \\
\hline $\begin{array}{l}\text { Keywords: } \\
\quad \text { Communication } \\
\text { International } \\
\text { Multilingualism } \\
\text { Professional } \\
\text { Trade }\end{array}$ & $\begin{array}{l}\text { In the era of globalization, knowledge of foreign languages has } \\
\text { become essential for companies looking to get into the international } \\
\text { market. Knowledge of English only is not enough to communicate } \\
\text { with countries where English is not the official language. Salespeople } \\
\text { are disadvantaged if they do not speak the language or do not know } \\
\text { the local client's culture. Multilingualism and interculturalism are } \\
\text { key and strategic instruments for establishing good business } \\
\text { relationship, professional communication with foreign customers, } \\
\text { business negotiations etc. Particularly in the EU, but also in Asia and } \\
\text { Latin America, much attention is paid to the role of multilingualism } \\
\text { and interculturalism in international trade. In this paper we present } \\
\text { the first international trade activities in which multilingualism and } \\
\text { interculturalism have an important role and the applicability of the } \\
\text { approach of the languages for specific purposes in the companies } \\
\text { planning to go to foreign markets. }\end{array}$ \\
\hline
\end{tabular}

\section{Introduction}

Over the past 20-30 years, the context in which companies operate has changed dramatically. Economic globalization has led to the rapid cross - border movement of goods, services, technology and capital, but also to rapid growth in the importance of information in all types of economic activity. Therefore, with globalization, the knowledge of languages and different cultures has become very important at the international trade. The international professional communication involves exchanges of opinions, discussions, negotiations, confrontations, conciliations of contradictory interests, compromise research and etc. The management of this type of professional communication is not possible without a good command of the language. In the beginning, the role and importance of plurilingualism and interculturalism in trade, economics and management in general, will be discussed, as well as measures taken by the EU on the issue of plurilingualism as a factor of economic growth. Next, will be illustrated the application of the language's approach for specific purposes in international export, in other words, at the companies which plan to be represented at the foreign markets.

\section{Importance of plurilingualism and interculturalism}

Plurilingualism and interculturalism, two related concepts, refer to apprehending other cultures, which could be considered a real human wealth. According to Etienne Davignon, Vice-President of the European Commission: “... a lingua franca would never satisfy the need of communication (...) Plurilingualism promotes openness and tolerance but also opens the door to new markets and new business opportunities." (Comission Européenne, 2008) By the way, it is not meant to diminish the importance of the English language in business, but to underline that only a small percentage of the world's population is able to speak it at a fluent level. It is true that English is the most used language in international trade, but many recent

* Corresponding Author E-Mail Address: kakova@abv.bg 
studies show that the knowledge of English language alone is not sufficient to communicate with countries where English is not the official language.

In addition, the policy of European integration is based on plurilingualism and interculturalism (Maurier, 2012). This is the reason why the EU pays great attention to intercultural education "... which recognizes the values, lifestyles and symbolic representations of individuals or societies ..." (Lafortune, 2000). At a business conference in Brussels named Languages Make Our Business, (Commission Européenne, 2007) the plurilingualism policy has been promoted at all levels. The main idea of this forum was that the plurilingualism policy could improve the European economy. It has been indicated what needs to be done to help companies to have access to new markets and new opportunities in a global world. The forum also gave examples of companies, which were successful thanks to improvement of language and intercultural skills. Despite of everything, in some European countries, was noticed the progressive extinction of the learning of several foreign languages, while the countries of Asia and Latin America, being aware of the importance of the knowledge of foreign languages, invest more and more in their education.

Intercultural knowledge is "the capacity of people to observe, analyze all the aspects of the behavior of their foreign counterparts, to become aware of it and to learn from it in order to adapt their own behavior" (Carras, Tolas et al., 2007). Intercultural communication means that the dialogue takes place on several levels at the same time, because it is not only the linguistic content that is exchanged, but also extra linguistic context. Intercultural awareness includes knowledge of social diversity, understanding the relationships between two cultures and the way each community appears in front of the other, often as stereotypes. In addition, the development of intercultural competences concerns all companies that have activities abroad. Since the 1990s, intercultural management has begun to develop primarily in the large international companies.

On the other hand, intercultural incompetence could cause significant interference and obstacles in professional communication. In order to limit obstacles and misunderstandings, it is necessary to observe the cultural specificities of the country, with which commercial cooperation is planned. The most important task in the management of foreign trade is the establishment of good business relations with foreign customers. Except the knowledge of the rules of international trade, the export also requires knowledge of the rules of appearance, communication and negotiation of the country concerned. Communicating with customers in a language they understand is also an important factor in generating trust. What stands out as the most common problem in the management of foreign trade and international sales is exactly the ignorance of foreign languages and cultures. Salespeople are disadvantaged if they do not speak the local client's language and do not know his culture.

\section{Application of the language approach for specific objectives}

For reasons mentioned above, it is obvious that a company considering going to the international market should primary have a culturally competent inter-professional employees, capable of managing professional communication in several languages. If this is not the case, the best solution is to apply the language approach for specific objectives according to the market that the company wants to conquer. In this way, companies would avoid potential problems that may occur due to the ignorance of foreign languages and cultures. The first stage in implementing the language for specific objectives approach is the precise definition of the company's demand. After defining demand, the next stage is to analyze the language needs of the company and its employees. The needs analysis is one of the most important stages in languages for specific objectives. The globalization of the economy and technological progress have led to the fact that each company has different needs. (Sigulinski, 1993) Once the needs are defined, the next stage is to collect data. The collection of data requires the teacher to 
address the field concerned, to get in touch with the players in the professional field concerned, to describe the workplace, to enquire about the situations of communication, to record or copy the authentic documents (Mangiante, 2015). When all the data is collected, it is necessary to do a detailed analysis. This analysis allows the identification of all the linguistic and extra linguistic particularities and all the details that could be taken into account. In this regard, the companies should learn about the specifics of business practices and habits such as business meetings, how to present themselves, gestures, schedules, holidays. The Common European Framework of Reference for Languages (Conseil d'Europe, 2000) proposes the characteristics of a culture to which everyone should pay attention while learning to know it. From the data collected and analyzed, the teacher develops his own material and develops his pedagogical tools. As these are languages in specific context, there is a great freedom in the organization of classes. The teacher must identify the professional situations of communication for teaching, the intercultural aspects and the language skills.

\section{Conclusion}

Taking into consideration of plurilingualism and interculturalism is seen as a key success factor for international trade. If companies do not realize the economic potential of plurilingualism and multiculturalism, they will lose the battle in the global competition with the companies of the new industrial countries. By developing, in this communication, the aspects of plurilingualism and interculturalism, contributed itself to the development of international trade and professional communication. Plurilingualism and interculturalism are hidden resources that should be exploited more, as the industrial economy is slowly turning into a knowledge-based economy.

\section{References}

Carras, C., Tolas J., Kohler, P., et al., (2007.) Le français sur objectifs et la classe de langue, Paris, CLE International, 207.

Commission Europeenne (2008) . Multilingualism: How languages help business. Retrieved from http://europa.eu/rapid/press-release_IP-08-1130_en.htm.

Commission Européenne (2007). Les langues font nos affaires. Retrieved from http://europa.eu/rapid/press-release_IP-07-1368_fr.htm?local=FR.

Conseil d'Europe (2000). Cadre européen commun de référence pour les langues, Strasbourg, Didier, 192

Lafortune L., Gaudet, E., (2000). Une pédagogie interculturelle - pour une éducation à la citoyenneté, St. Laurent, ERPI, .304

Maurier, B., (2011). Enseignement des langues et construction européenne. Le plurilingualisme, nouvelle idéologie dominante, Paris, Edition des archives contemporaine, 156.

Mayrhofer, U., Urban, S., (2011). Management international - des pratiques en mutation, Paris, Pearson, 312

Sigulinski, S. A., (1993). International trade business management, Novi Sad, Pigmalion, 366. 